\title{
Impact of $\mathrm{Zn}-\mathrm{Pb}$ mining in the Olkusz ore district on the Permian aquifer (SW Poland)
}

\author{
Jacek Motyka $\cdot$ Adam Postawa
}

Received: 4 January 2013 / Accepted: 15 April 2013 / Published online: 1 May 2013

(C) The Author(s) 2013. This article is published with open access at Springerlink.com

\begin{abstract}
Long-term extensive mining of $\mathrm{Zn}-\mathrm{Pb}$ ores in the Olkusz area resulted in significant changes of water table levels and chemical composition of water in all aquifers in this area. Within the Permian aquifer, hydrochemical type of water evolved in two general stages. Short-term effect was freshening in the zones of contact with overlying the Triassic limestones and dolomites. Long-term effect was a change in flow pattern and, as a consequence, an inflow of naturally altered and antropogenically contaminated water from the Triassic aquifer into the Permian complex. This was especially intensive in densely fissured and fault zones. As a result of all these processes, hydrochemical type of water shifted from multi-ion types with various combinations of ions towards higher shares of sulphates, calcium and magnesium.
\end{abstract}

Keywords $\mathrm{Zn}-\mathrm{Pb}$ ore mining · Groundwater chemistry evolution $\cdot$ Mining drainage $\cdot$ Olkusz

\section{Introduction}

Underground mining usually requires dewatering of excavations during accessing stage and very often also during exploitation stage. Mining drainage can cause significant changes in water table and chemical composition of water within aquifers surrounding the mining area.

Responsible editor: Philippe Garrigues

J. Motyka $\cdot$ A. Postawa $(\bowtie)$

AGH University, Al. Mickiewicza 30,

30-059 Krakow, Poland

e-mail: postawa@agh.edu.pl

J. Motyka

e-mail: motyka@agh.edu.pl
The history of the mining of metals in Olkusz region reaches back to neolith. It is confirmed by documents from the twelfth century. At first, $\mathrm{Pb}$-ore containing silver was extracted from the Triassic deposits located above the groundwater level. After depletion of the ore deposits located in the aeration zone, dewatering of the Triassic rocks became necessary so that exploitation could reach deeper. In the seventeenth century, a number of adits were excavated in order to drain water from ore-bearing rocks. That caused decrease in the water table by $30 \mathrm{~m}$ in surrounding areas. This period is considered as the beginning of mining drainage in the Olkusz area. However, intensive mining drainage of the Triassic aquifer dates back to half of the twentieth century. At this time, the Bolesław Mine, which was active for the nineteenth century, was dewatered again and two new mines were established: Olkusz and Pomorzany. For the issues discussed in this work, construction of the Pomorzany Mine, which began in 1969, is very important. The main accessing excavations were carried out in the Permian molasse underlying the Triassic formation. At the beginning of the 1990s, another part of the $\mathrm{Zn}-\mathrm{Pb}$ deposit was accessed by the Olkusz Sublevel Mine. Accessing excavations were also carried out in the Permian molasse.

The main subject of this study was to assess the influence of intensive mining drainage in the Olkusz area on chemical composition of water within the Permian formation. Series of archival data were confronted with the results of chemical analyses of water samples collected during the last 40 years.

\section{Site characterisation}

Geological settings

Along the eastern, north-eastern and northern edging of an Upper Silesian coal basin stretches bow-shaped, narrow zone of the Permian sediments. During the Permian period, 
this area was a land with hot and dry climate. As a result of the Wariscian orogeny, a narrow, but quite deep intermountain graben-oriented north-west to south-east came into existence and most probably deepened in the Permian. The graben is bordered by elevated blocks: Upper Silesian from south-west and Lesser Poland from the south-east (Buła 2000). Erosion of these tectonic blocks, in particular the Lesser Poland block, served as a source of clastic material which filled the valley. Moreover, an active volcanic activity took place in this region. Numerous intrusions that were observed in the area south-east of Olkusz confirm this activity (Kozłowski 1955).

Climatic conditions favoured typical for deserts kind of physical erosion (i.e. insolation and physical weathering) which led to the decomposition of rock outcrops. Periodic streams and rivers with great kinematic energy facilitated the transport of clastic material and filled the graben valley with typical molasse with signs of volcanic activity. These are mostly conglomerates of Palaeozoic rocks, mostly Carboniferous and Devonian limestones and dolomites along with quartz and quartzite and volcanic rocks: porphyries and melaphyrs. The cement consists of all sorts of small fractions, argillaceous to sandy with the varying share of tuff. The molasse is generally formed of poorly sorted rocks' grains. However, in the Olkusz area, a certain tendency toward reduction of grain sizes along the line from the Lesser Poland block to the south-west is noticeable. During this period, in large endorheic basins located far from the eroded rock outcrops the smallest argillaceous fractions were deposited. In this way, to the west of Olkusz in the area of Sławków, so-called Sławków loams were formed (Siedlecka 1964). Within those loams, characteristic secondary fibrous gypsum that re-crystallised in fissures can be found, locally called gypsum veins.

The thickness of the Permian sediments varies significantly and depends on the morphology of older, prePermian rocks (Ekiert 1971). Two big marine transgressions that occurred in the Mesozoic (Rethian and Dogger) to a large extent denudated and peneplenised older surface that was formed on the base of Palaeozoic rocks. In the central part of the intermountain trench, which is filled with molasse, the thickness of these sediments reaches up to $300 \mathrm{~m}$. In the eastern and north-eastern parts of the Olkusz area, the Permian molasse has not been found in drillings.

\section{Hydrogeological conditions}

In the Olkusz area, four major aquifers are distinguished: Quaternary, Jurassic, Triassic and Carboniferous-Devonian (Palaeozoic). Additionally, the Permian molasse is considered as a secondary aquifer.

Quaternary aquifer consists of heterogeneous fluvioglacial sands and gravels and residual rubbles. Quaternary sediments reach maximum thickness of 50-70 $\mathrm{m}$ (Motyka 1988) in central parts of buried valleys which were developed before
Pleistocene glacial period. Geometric mean value of hydraulic conductivity, calculated on the base of pumping tests, is 2.5 . $10^{-4} \mathrm{~m} / \mathrm{s}$ (Motyka and Wilk 1976).

Jurassic aquifer is of a fissure-karstic type and comprises Upper Jurassic limestones occurring in eastern and northern parts of Olkusz region. The thickness of Jurassic limestones reaches up to about $200 \mathrm{~m}$. Average hydraulic conductivity (calculated as geometric mean, on the base of pumping tests) is $1.5 \cdot 10^{-5} \mathrm{~m} / \mathrm{s}$ (Motyka and Wilk 1976).

The Triassic aquifer consists of dolomites and limestones of lower and middle Triassic (Upper Buntsandstein and Lower and Middle Muschelkalk). This aquifer belongs to a porousfissured-karstic type (Motyka 1998). Average hydraulic conductivity equals $6.5 \cdot 10^{-5} \mathrm{~m} / \mathrm{s}$. The Triassic dolomites and limestones in the Olkusz area are also the host rocks for $\mathrm{Zn}-$ $\mathrm{Pb}$ ores. Drainage of the excavations was necessary so that ore extraction was possible. The drainage resulted in significant decrease of groundwater table. In the vicinity of excavations, the water table dropped $80 \mathrm{~m}$ in the Bolesław Mine area, $100 \mathrm{~m}$ near the Olkusz Mine and $130 \mathrm{~m}$ in the Pomorzany Mine area.

The majority of the Olkusz area, Triassic limestones and dolomites lie on the Permian molasse which is represented by monotonous series of poorly assorted, red conglomerates of terrestrial origin, interbedded by sandstones and mudstones. Total thickness of molasse complex reaches $300 \mathrm{~m}$. The Permian aquifer belongs to porous-fissured type. It is believed, that in the regional scale, the molasse complex acts rather as an aquitard separating the Triassic and Devonian aquifers. However, during excavation of shafts and galleries, very often miners have been encountering local zones of increased permeability (mostly in fissured rocks) with seepages and inflows with yields from tenths of litres per minute up to hundreds of litres per minute. Pumping tests ( 6 tests in 2 wells) and slug tests (26 tests in 12 boreholes) showed significant variability in hydraulic conductivity values, from 2.5 . $10^{-8}$ to $1.6 \cdot 10^{-5} \mathrm{~m} / \mathrm{s}$ and from $1.0 \cdot 10^{-7}$ up to $5.4 \cdot 10^{-5} \mathrm{~m} / \mathrm{s}$, respectively (Adamczyk et al. 1978).

The Palaeozoic aquifer is of fissured type and consists of limestones and dolomites of Lower Carboniferous and Middle Devonian. Hydrogeological conditions in the Palaeozoic carbonates are poorly recognized. Hydraulic conductivity was measured only twice by pumping tests which presented values of $7.6 \cdot 10^{-6}$ and $7.0 \cdot 10^{-5} \mathrm{~m} / \mathrm{s}$, respectively.

\section{Mining context}

The mining methods implemented during development of the Pomorzany Mine were influenced by two major factors: geological conditions and expected large inflows of water from the Triassic limestones and dolomites, especially during initial stage of excavations.

Location of ore deposits exploited by the Olkusz and Pomorzany Mines had crucial meaning. Both deposits occur 
in grabens which are separated by Olkusz horst (Fig. 1). Olkusz deposit is located within Olkusz graben while Pomorzany deposit occupies a hanging wall block of Pomorzany fault (see Fig. 2).

Development of the Olkusz Mine began in the 1960s. The ore deposit was accessed with shaft and galleries at the $+238 \mathrm{~m}$ above sea level (a.s.1.). Only short run of main gallery was excavated in the Permian sediments (see Fig. 2). There is no available information about any inflows in this part of the gallery.

In the early 1970s, a decline in the Permian conglomerates was excavated from the Olkusz Mine reaching $+175 \mathrm{~m}$ a.s.l. which started a development of the Pomorzany Mine. At first, a main gallery was excavated towards west, approximately along the Pomorzany fault; then six secondary drifts towards the north were made. The secondary drifts, perpendicular to the Pomorzany fault and crossing it, allowed draining water from the Triassic rocks located below the ore deposits. This method of accessing the deposits was very expensive and unjustified from an economic point of view. In that time, it was unique in the world. About $10 \mathrm{~km}$ of galleries were excavated in the Permian conglomerates in order to access $\mathrm{Zn}-\mathrm{Pb}$ ores in the Pomorzany Mine and nearly 80 inflows and seepages were reported during that time.

In the 1990s, another part of the Olkusz Mine was developed. It was called the Olkusz Sublevel and was located within a small secondary graben oriented north-west to south-east (see Fig. 2). Part of main accessing gallery and dewatering drafts, with a total length of approximately $2 \mathrm{~km}$, was excavated in the Permian conglomerates at $+175 \mathrm{~m}$ a.s.l. A number of inflows coming from molasse were reported.

\section{Sampling and analytical methods}

Water samples were collected mostly from inflows and seepages in shafts and drifts excavated in the Permian conglomerates. In the period from 1970 to 2011, a total of 198 samples were collected. Samples were also collected, as far as possible, from exploratory boreholes drilled during deposit documentation and exploration stages, piezometers and wells located in investigated area. Unfortunately, in many samples, only selected parameters were determined, thus the number of complete analyses is smaller (i.e. 160).

All analyses were conducted in the Hydrochemical Laboratory of Department of Hydrogeology and Engineering Geology, AGH University, Krakow. Standard analytical methods were used. Chloride concentrations were determined using Mohr method (i.e. titration with silver nitrate). Alkalinity was determined by titration with hydrochloric acid and then hydrocarbonate concentration was calculated. Until 1990, sulphate concentrations were determined using gravimetric method with drying of residue. Since 1990, inductively coupled plasma atomic emission spectroscopy (ICP-AES) is used; the total sulphur content is determined and then sulphate concentration is calculated. In samples collected before 1990, calcium
Fig. 1 Schematic of major excavations of the Pomorzany and Olkusz Mines

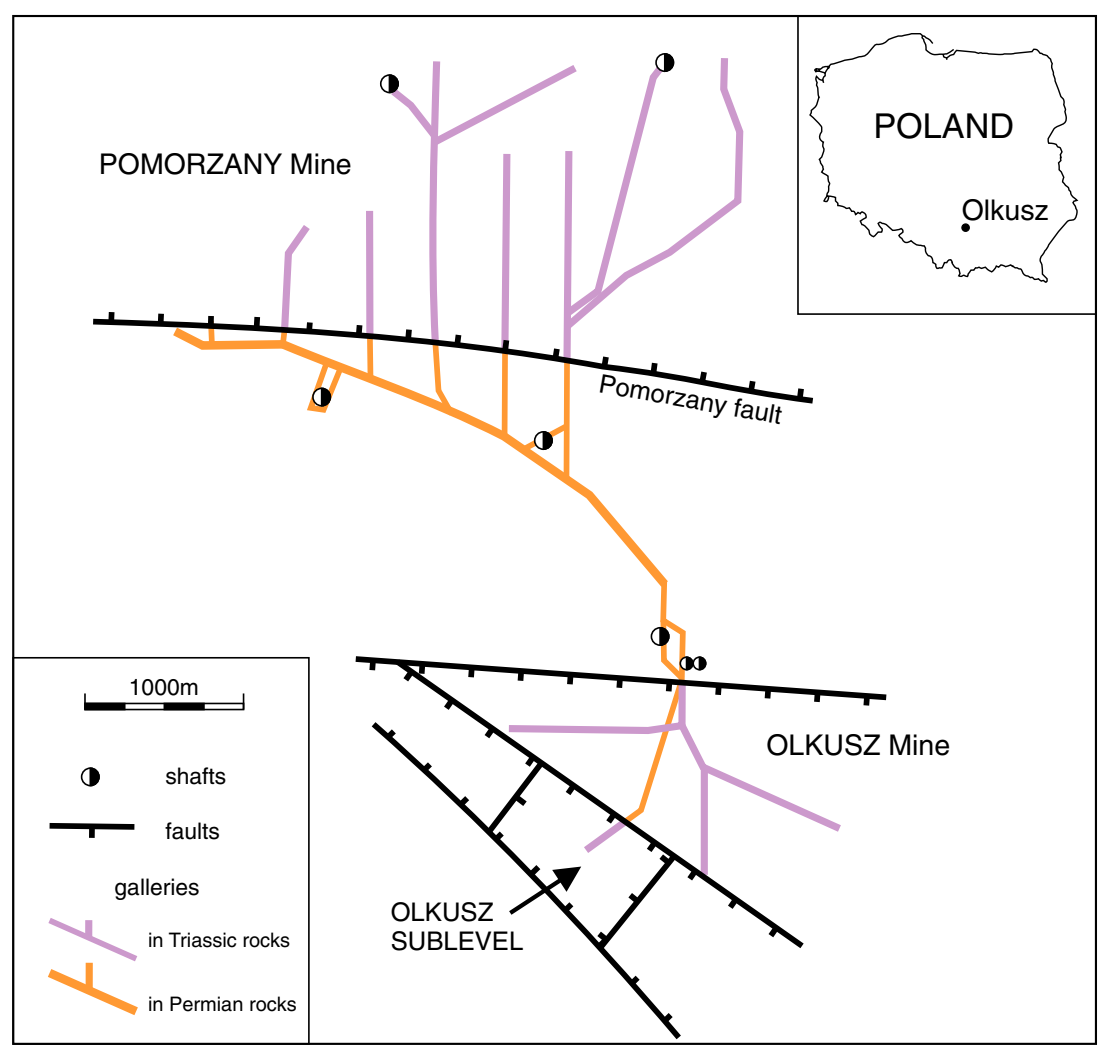


Fig. 2 Schematic

hydrogeological cross-section

through Olkusz ore district

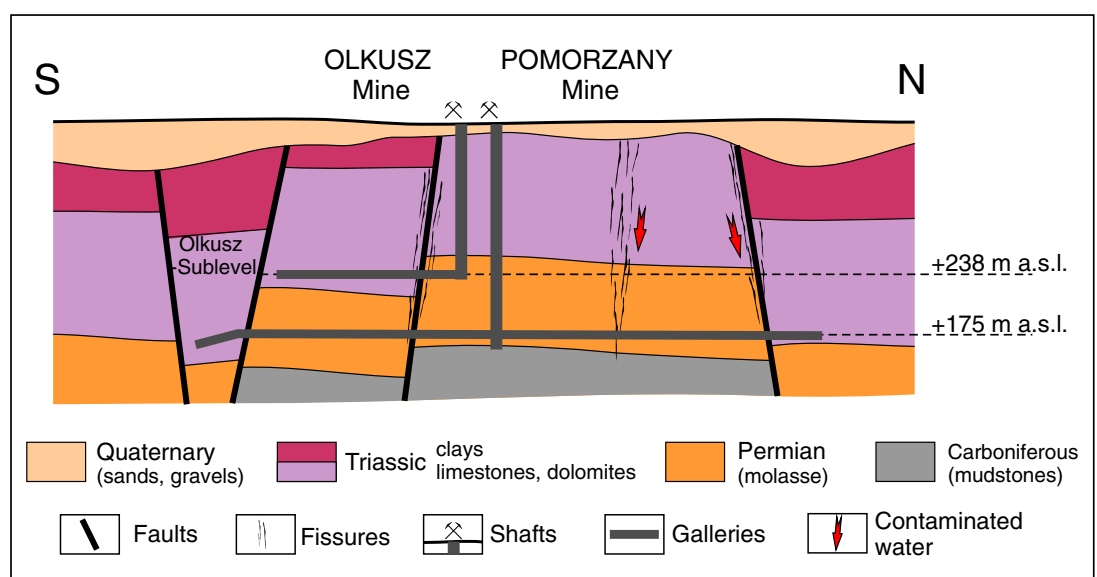

was determined by EDTA titration. Magnesium concentrations were calculated on the base of total hardness and calcium. Sodium and potassium were determined by flame emission photometry. Since 1990, all these metals are determined by ICP-AES method.

\section{Results and discussion}

Pomorzany Mine-initial stage

During initial stages of mine development, chemical composition of water flowing into excavations developed in the
Permian conglomerates varied significantly (Motyka et al. 1972; Adamczyk et al. 1978). Total dissolved solids (TDS) value ranged from 0.33 to $21.6 \mathrm{~g} / \mathrm{L}$.

Water with TDS below $1 \mathrm{~g} / \mathrm{L}$ belonged to multi-ion type with various combinations of ions from $\mathrm{Cl}-\mathrm{SO}_{4}-$ $\mathrm{HCO}_{3}-\mathrm{Ca}-\mathrm{Mg}-\mathrm{Na}$, Na-Mg-Ca-Cl- $\mathrm{SO}_{4}-\mathrm{HCO}_{3}, \mathrm{Na}-\mathrm{Ca}-$ $\mathrm{Mg}-\mathrm{HCO}_{3}-\mathrm{Cl}-\mathrm{SO}_{4}$ or $\mathrm{HCO}_{3}-\mathrm{Cl}-\mathrm{Na}-\mathrm{Mg}-\mathrm{Ca}$ to $\mathrm{HCO}_{3}-$ $\mathrm{Ca}-\mathrm{Mg}-\mathrm{Na}$. It was observed that with increasing mineralisation, amongst cations, a share of magnesium and sodium increased at the expense of calcium (see Fig. 3).

Amongst anions a role of sulphates and chlorides increased with decreasing share of bicarbonates. As
Fig. 3 Piper diagram of groundwater in the Permian aquifer in natural conditions

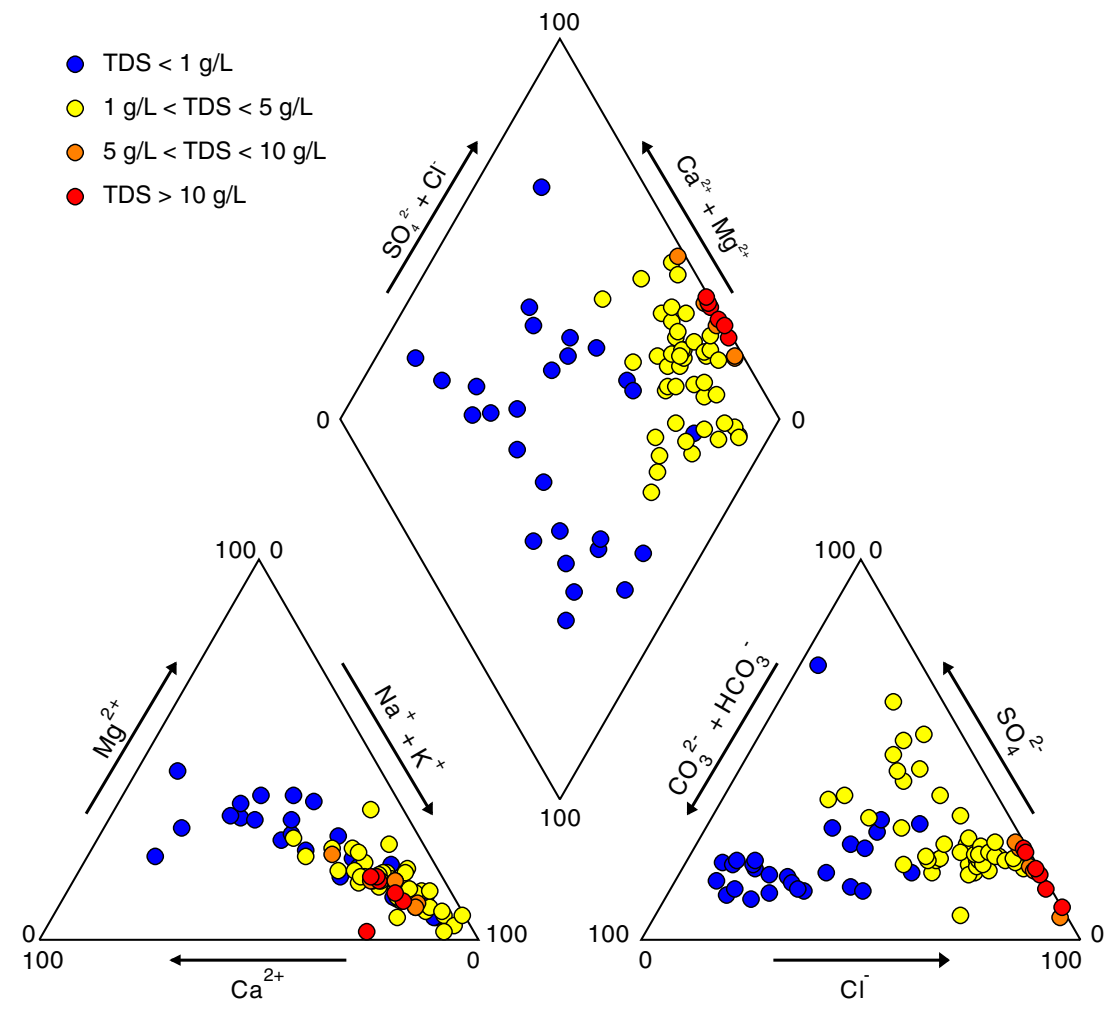


mining excavations were reaching lower levels and the thickness of the Permian overburdens increased, mineralisation of water from inflows also increased. Hydrochemical type of water with TDS values from 1 to $5 \mathrm{~g} / \mathrm{L}$ has changed. Most of them belonged to $\mathrm{Na}-$ $\mathrm{Cl}-\mathrm{SO} 4$ or $\mathrm{Na}-\mathrm{SO} 4-\mathrm{Cl}$ type, in some cases with increased share of calcium or magnesium.

In waters with TDS value above $5 \mathrm{~g} / \mathrm{L}$, chlorides and sulphates dominated amongst anions and sodium ion was a dominating cation. Most water belonged to $\mathrm{Na}-\mathrm{Cl}-\mathrm{SO}_{4}$ hydrochemical type, on occasion with increased share of magnesium and calcium. In highly mineralised waters, with TDS above $10 \mathrm{~g} / \mathrm{L}$, distinctly dominated chlorides and sodium, thus these waters belonged to $\mathrm{Na}-\mathrm{Cl}$ type. Waters with high TDS were usually observed in eastern part of the Pomorzany Mine while low mineralised waters were typical for the western part.

\section{Olkusz Sublevel Mine_-initial stage}

Waters flowing into mine excavations from the Permian conglomerates presented lower values of total mineralisation than those in the Pomorzany Mine. TDS ranged from 0.37 to $2.34 \mathrm{~g} / \mathrm{L}$. Waters of lowest mineralisation, mostly belonging to $\mathrm{HCO}_{3}-\mathrm{Ca}-\mathrm{Mg}$, occurred in the fault zone, where the Permian conglomerates and the Triassic carbonate rocks were in contact. Relatively large share of low mineralised water from the Triassic aquifer mixed with water circulating in the Permian complex. As a result of this process, water flowing into excavations presented chemical composition similar to water in the Triassic aquifer. While waters with higher TDS belonged to $\mathrm{Na}-\mathrm{Cl}-\mathrm{SO}_{4}$ in the vicinity of a fault chemical type of water changed, first to $\mathrm{Na}-\mathrm{SO}_{4}-\mathrm{HCO}_{3}$, then to $\mathrm{Na}-$ $\mathrm{HCO}_{3}$ (see Fig. 3).

Changes in chemical composition of water inflows

The majority of inflows in the eastern part of the Pomorzany mine became inactive in the natural way in the period from a dozen or so hours up to a few months. Others were stopped by tight linings used in galleries. Few of them were active for longer periods of time, thus observation of the evolution of their chemical composition was possible. A good example is an inflow from an exploratory borehole no 243 which was monitored from 1972 to 1982 . Initially, the mineralisation was $7.6 \mathrm{~g} / \mathrm{L}$. During the first year after drilling, TDS decreased to $1.1 \mathrm{~g} / \mathrm{L}$; then in the consecutive year, an increase in $1.7 \mathrm{~g} / \mathrm{L}$ was noticed. This value remained approximately constant till the end of observation period. TDS and chloride concentration may serve as indicators of the changes in chemical composition of water from this inflow (see Fig. 4).

From the moment of the inflow appearance, the concentration of chloride ion was very quickly decreased, then stabilised. Rapid decrease in mineralisation of waters flowing from the Permian conglomerates in the eastern part of the Pomorzany Mine, under the influence of mining drainage, was observed at all points, in which at least two water samples were collected in different times. Concentration of sulphates increases along with increase in calcium and manganese concentrations.

In the western part of the Pomorzany mine, changes of the chemical composition of inflows from the Permian conglomerates are caused not only by a buffering of acid solutions in the environment of carbonate rocks, but also by polluted waters from carbonate Triassic rocks from the south. Pollution is caused by the migration of leakage from tailing ponds located near the Bolesław Mine. During the development stage of the Pomorzany Mine, only five inflows in this part of the mine were registered. Those were freshwaters with TDS from 0.38 to $0.59 \mathrm{~g} / \mathrm{L}$. Calcium concentration ranged from 24 to $58 \mathrm{mg} / \mathrm{L}$, magnesium from 20 to $34 \mathrm{mg} / \mathrm{L}$, sodium from 7 to $83 \mathrm{mg} / \mathrm{L}$ and potassium from 5 to $6 \mathrm{mg} / \mathrm{L}$. As for the anions, chloride concentration ranged from 16 to $90 \mathrm{mg} / \mathrm{L}$, sulphates from 40 to $128 \mathrm{mg} / \mathrm{L}$ and bicarbonate from 232 to $250 \mathrm{mg} / \mathrm{L}$. At those times, waters from the inflows belonged to the general type $\mathrm{HCO}_{3}-\mathrm{Ca}-\mathrm{Mg}$ and in one case $\mathrm{HCO}_{3}-$ $\mathrm{SO}_{4}-\mathrm{Ca}-\mathrm{Mg}$ (Fig. 5).

Water samples collected from inflows in this part of the Pomorzany Mine in years 1996-2010 presented completely different chemical composition. TDS ranged from 1.47 to $5.14 \mathrm{~g} / \mathrm{L}$. Among cations, calcium and magnesium noticeably dominated with concentrations ranging from 220 to $550 \mathrm{mg} / \mathrm{L}$ and from 98 to $460 \mathrm{mg} / \mathrm{L}$, respectively. An

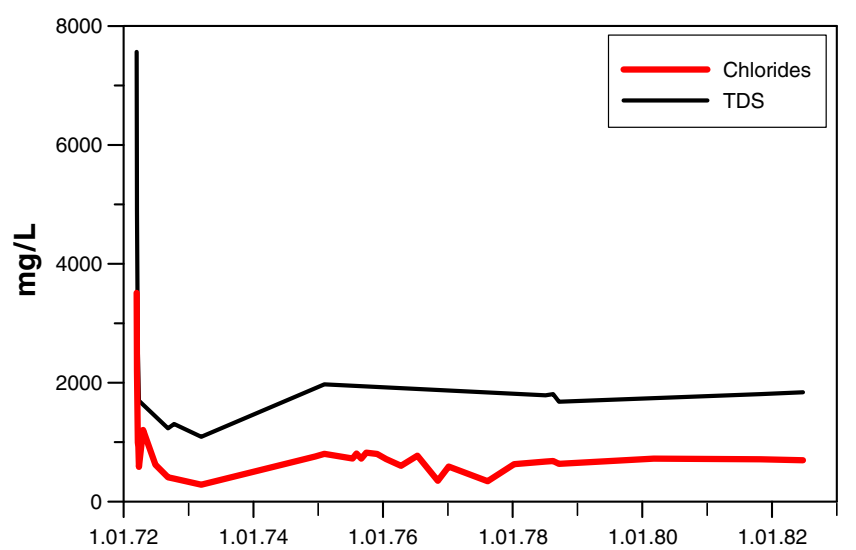

Fig. 4 Changes in TDS and chloride concentration in water from inflow no 243 
Fig. 5 Chemical composition of water in eastern part of the Pomorzany Mine

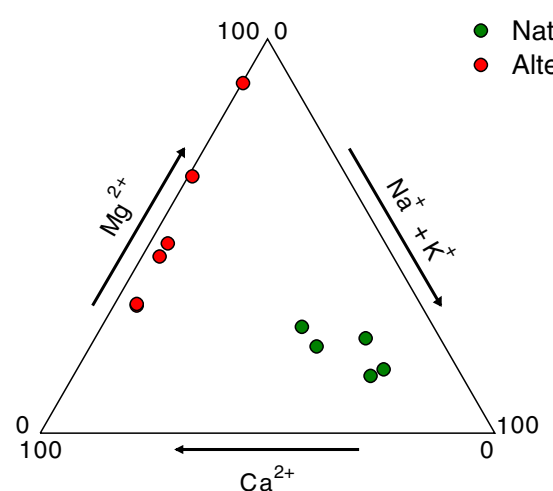

- Natural waters

Altered waters

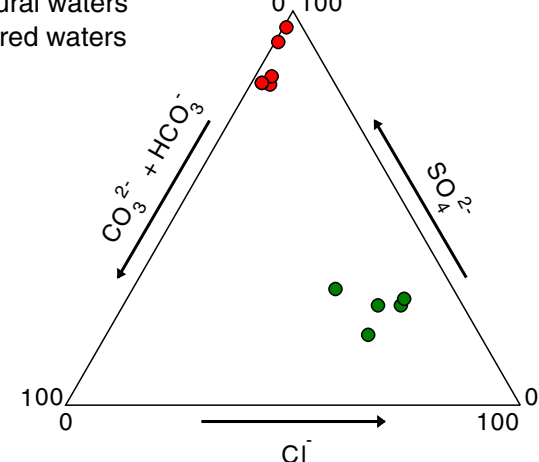

increase in sodium concentration was also observed (12 to $150 \mathrm{mg} / \mathrm{L}$ ). Only potassium concentration was practically unchanged, ranging from 3 to $9 \mathrm{mg} / \mathrm{L}$. With significant changes in relations between major ion concentrations, chemical types of discussed waters changed to $\mathrm{Ca}-\mathrm{Mg}-\mathrm{SO}_{4}-\mathrm{HCO}_{3}$ or $\mathrm{SO}_{4}-\mathrm{Ca}-\mathrm{Mg}$ and $\mathrm{SO}_{4}-\mathrm{Mg}-\mathrm{Ca}$ (Fig. 6).

In the Olkusz Sublevel Mine, almost all inflows from the Permian molasses either vanished or were eliminated by tight lining of mining excavations. Only one inflow remained active (OPP-8) in the fault zone where the Permian molasse contacts with carbonate Triassic rocks. Therefore, water from this inflow most probably comes from the mixing of waters from mining works in the Permian and in the Triassic rocks. In the period from June 2001 up to February 2011, five analyses of the chemical composition of waters were performed. During that time, a distinct evolution of the chemical composition of water from this inflow was observed. The TDS of water increased from $390 \mathrm{mg} / \mathrm{L}$ in 2001 through $440 \mathrm{mg} / \mathrm{L}$ in years 2004 and 2005 up to $620 \mathrm{mg} / \mathrm{L}$ in 2010 and of $630 \mathrm{mg} / \mathrm{L}$ in 2011. It was associated with the increase in the concentration of sulphates from $71 \mathrm{mg} / \mathrm{L}$ in 2001 up to $90 \mathrm{mg} / \mathrm{L}$ in years 2004 and 2005 and $117 \mathrm{mg} / \mathrm{L}$ in 2010 and of $203 \mathrm{mg} / \mathrm{L}$ in 2011. Following the increase in the concentration of sulphates, concentration of calcium also increased from $78 \mathrm{mg} / \mathrm{L}$ in 2001 up to $122 \mathrm{mg} / \mathrm{L}$ in 2011 along with magnesium from $17 \mathrm{mg} / \mathrm{L}$ in 2001 up to $35 \mathrm{mg} / \mathrm{L}$ in 2011.

Effects of mining drainage on water chemistry

The evolution of groundwater chemical composition in the Permian aquifer should be considered in two ways: as short- and long-term effects. At the initial stage of Pomorzany Mine development, it was observed that with increasing depth, measured from the roof of molasse complex, TDS increased. Vertical hydrochemical zonality was also observed. Along with increase in TDS, the water hydrochemical type started to change. Water with total mineralisation of single grams per litre showed tendency toward decreasing mineralisation in zones of fissures or small faults.

Fast freshening of water flowing into excavations can be explained by seepage of less mineralised water from upper part of molasse complex and most probably also freshwater from the Triassic limestones and dolomites overlying the Permian conglomerates. In this case, a process of mixing waters with different mineralisation occurred, induced by decrease in natural pressure heads under the influence of mining drainage.

In long-term perspective, when flow conditions reach semi-steady state, migration of contaminated water
Fig. 6 Chemical composition of water in western part of the Pomorzany Mine

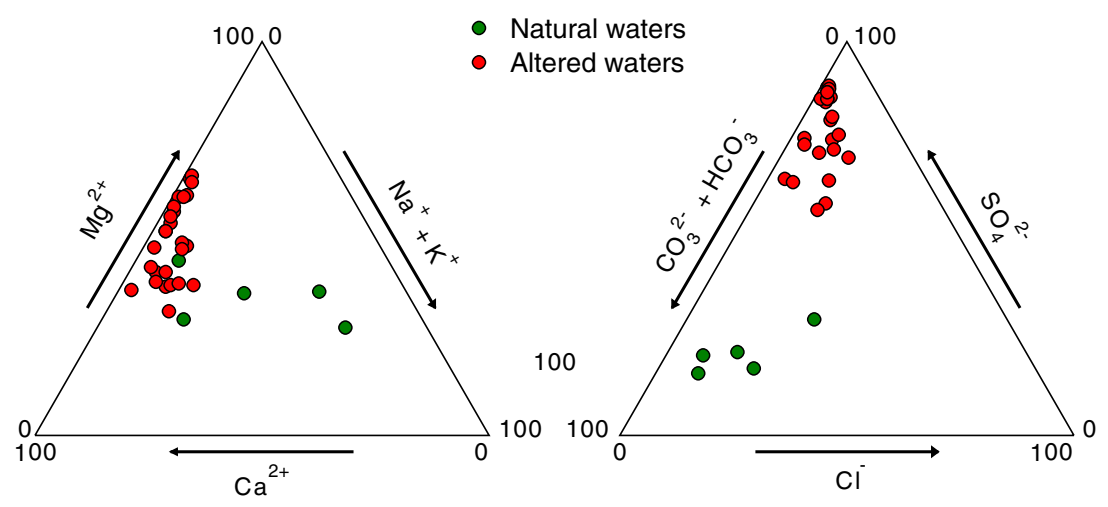


Fig. 7 Evolution of the chemical composition of water in western part of the Pomorzany Mine

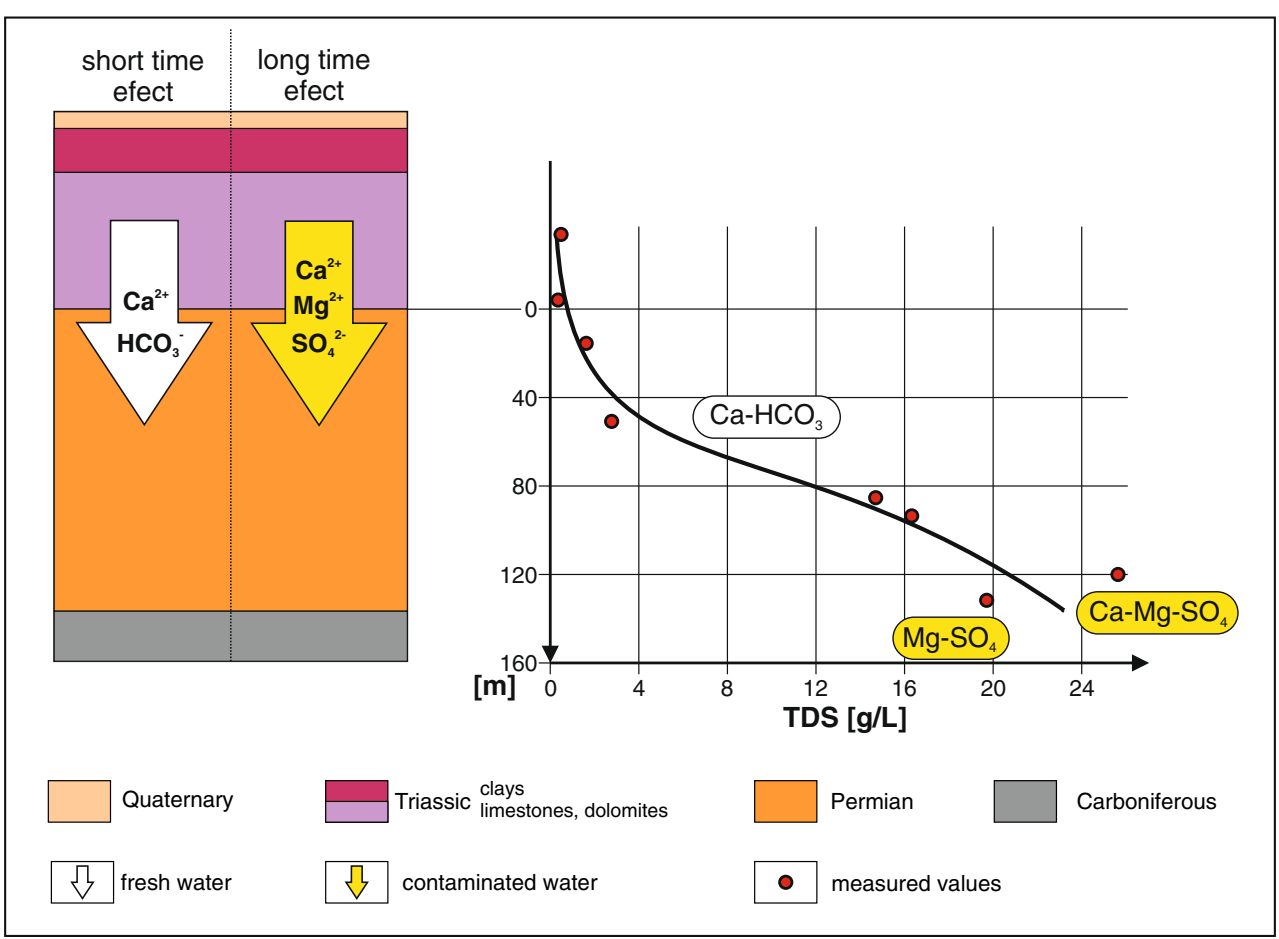

from the Triassic aquifer began to affect the chemical composition of inflows observed in the Permian conglomerates (see Fig. 7).

In the eastern part of the Pomorzany Mine, the chemical composition of the water in the Permian sediments was strongly influenced by products of sulphide minerals oxidation (mostly marcasite) which accompanied the $\mathrm{Zn}-\mathrm{Pb}$ ores. Oxidation of iron sulphides produces acid solutions (Singer and Stumm 1970) which are neutralised in contact with carbonate rocks and the $\mathrm{pH}$ value changes toward more alkaline. As a result of this process, in buffered solution, concentration of calcium and magnesium significantly increased (Fig. 7). The chemical type of the water in the eastern part of the Pomorzany Mine has changed to $\mathrm{Ca}-\mathrm{Mg}-\mathrm{SO}_{4}$ and $\mathrm{Mg}-\mathrm{Ca}-\mathrm{SO}_{4}$ or $\mathrm{Mg}-\mathrm{SO}_{4}$.

The most probable reason for the change of the chemical composition of water in the Olkusz Sublevel Mine seems to be a migration of polluted waters from western direction where liquidated Bolesław $\mathrm{Zn}-\mathrm{Pb}$ ore mine was located. Development of the Olkusz Sublevel Mine and the drainage of the Triassic carbonate rocks facilitated water flow from that direction. In this area, the groundwater in the Triassic (carbonate) aquifer showed practically constant concentration of sulphates from $2,500 \mathrm{mg} / \mathrm{L}$ to a maximum value of $4,800 \mathrm{mg} / \mathrm{L}$ (Motyka et al. 2005). To a certain degree, also weathering of sulphides, mostly $\mathrm{FeS}_{2}$, followed by buffering of acid solutions enriched in sulphates, calcium and magnesium, in the Triassic carbonates, could influence the chemical composition of inflow water. It is particularly probable since this inflow appeared in the fault zone.

\section{Conclusions}

Mining drainage with mining excavations of $\mathrm{Zn}-\mathrm{Pb}$ ore mines in the Olkusz area significantly affected the chemical composition of groundwater in the Permian aquifer. During the initial stage of mines development, the most significant process was groundwater freshening occurring in uppermost part of the Permian complex. It was caused by a contact with low mineralised water from the Triassic (carbonate) aquifer.

Intensive mining activities and the accompanying drainage of the Permian and the Triassic aquifers induced further evolution of chemical composition of groundwater. Products of iron sulphides weathering migrated from the Triassic limestones and dolomites and changed hydrochemical type of water in the Permian aquifer. Additionally, changes in groundwater flow directions caused migration of contaminated water from west, where closed the Bolesław Mine is located. These processes are especially intense in fault zones which serve as a preferential flow paths.

Acknowledgments This research was financially supported by the Polish Ministry of Science and Higher Education and (AGH University, statutory research no. 11.11.140.026). 
Open Access This article is distributed under the terms of the Creative Commons Attribution License which permits any use, distribution, and reproduction in any medium, provided the original author(s) and the source are credited.

\section{References}

Adamczyk AF, Motyka J, Wilk Z, Witczak S (1978) Salt water in Permian sediments on the north-eastern border of the Upper Silesia Coal Basin. Ann Societ Geol Pol 48(3-4):537-558 (in Polish)

Buła Z (2000) The Lower Palaeozoic of Upper Silesia and west Małopolska. Prace Państwowego Instytutu Geologicznego 171:89p (in Polish)

Ekiert F (1971) Geological structure of the sub-Permian basement of the north-eastern margin of the Upper Silesian Coal Basin. Prace Instytutu Geologicznego 56:77p (in Polish)

Kozłowski S (1955) Porphyric intrusions in the Dębnik Ridge. Biuletyn Instytutu Geologicznego 97:39-102 (in Polish)
Motyka J (1988) Triassic carbonate sediments of Olkusz-Zawiercie ore-bearing district as an aquifer. Scientific Bulletins of Stanisław Staszic Academy of Mining and Metallurgy No 1157, Geology 36 (in Polish)

Motyka J (1998) A conceptual model of hydraulic networks in carbonate rocks, illustrated by examples from Poland. Hydrogeol J 6:469-482

Motyka J, Wilk Z (1976) Vertical differentiation in the water permeability of carbonate Triassic rocks in the light of a statistical analysis of the results of pumping tests (Silesia-Cracow monocline). Geol Q 20(2):381-399 (in Polish)

Motyka J, Niewdana J, Witczak S (1972) Method of forecasting flooded fault zone under the conditions of a zinc and lead mine. Zeszyty Naukowe AGH 37:144-156 (in Polish)

Motyka J, Adamczyk Z, Czop M, d'Obyrn K (2005) Groundwater quality impact by municipal sanitary landfill in Ujkow near Olkusz (S Poland). Mineral Res Manage 21(1):131-153 (in Polish)

Siedlecka A (1964) Permian in the north-eastern border of the Upper Silesia Coal Basin. Annals of Polish Geol Soc 34(3):309-394 (in Polish)

Singer PC, Stumm W (1970) Acid mine drainage: the rate-determining step. Science 167:1121-1123 